\title{
Water balance of a sugarcane crop: Quantitative and qualitative aspects of its measurement
}

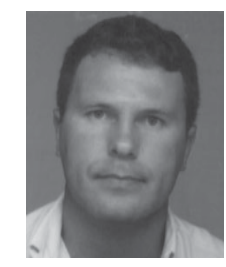

\author{
Luis C. Timm ${ }^{1,2}$, Julio C. M. de Oliveira ${ }^{3}$, Tania T. Tominaga ${ }^{1}$, Fabio A. M. Cássaro ${ }^{1,4}$, \\ Klaus Reichardt ${ }^{1,5}$ \& Osny O. S. Bacchi ${ }^{1}$
}

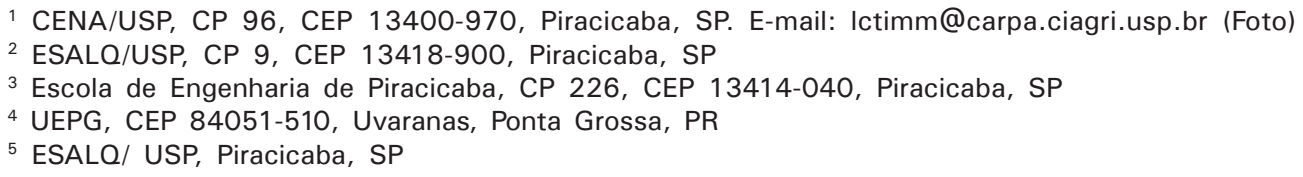

Protocolo $169-30 / 11 / 2001$

\begin{abstract}
The quantification of soil water balance components was conducted in a sugarcane (Saccharum officinarum L.) field differently managed, as well as a qualitative analysis of the methodologies used for their estimation. The study was conducted in randomized block experiment with four replicates and three treatments: bare soil, mulched soil using trash left on the soil surface after harvest, and soil with burnt trash. The soil was classified as a Rhodic Kandiudalf, locally called 'Terra Roxa Estruturada', the experimental area having a slope of $7.4 \%$. Run-off, soil water fluxes at the lower soil volume limit, and soil water storage changes were not affected by the different soil management practices. Furthermore, it was found that the evaluation of runoff and soil water fluxes is strongly affected by the spatial variability of physical properties.
\end{abstract}

Key words: water balance, soil physical properties, soil management

\section{Balanço hídrico de uma cultura de cana-de-açúcar: aspectos quantitativos e qualitativos de suas medidas}

\begin{abstract}
Resumo: A quantificação e as análises qualitativas das metodologias para estimar os componentes do balanço hídrico em um solo submetido a diferentes práticas de manejo, foram estudadas em uma área experimental de cana-de-açúcar (Saccharum officinarum L.) utilizando-se blocos distribuídos ao acaso, com quatro repetições e três tratamentos: solo nu, solo com resíduos de palhiço e ponteiros, deixados na superfície do solo após a colheita e solos com resíduos da queima. O solo foi classificado como um Rhodic Kandiudalf chamado, localmente, de 'Terra Roxa Estruturada', tendo a área experimental uma inclinação de 7,4\%. O escoamento superficial, os fluxos de água nos limites inferiores do volume do solo e as mudanças do armazenamento da água do solo, não foram afetadas pelas diferentes práticas de manejo. Além disso, encontrou-se que o escoamento superficial e os fluxos da água do solo são fortemente afetados pela variabilidade espacial das propriedades físicas do solo.
\end{abstract}

Palavras-chave: balanço hídrico, propriedades físicas do solo, manejo do solo

\section{INTRODUCTION}

There are several methodologies to estimate the water demand of the different growth stages of agricultural crops, each of them having specific characteristics with respect to the inputs used for their estimation. Among these, the crop water balance performed directly in the field allows the monitoring of water relations during distinct growth and development stages, being, therefore, very important for a rational management of soil and water resources, and for the maximization of the productivity.

The water balance evaluated through the quantification of the available water depth in a given soil profile is based on mass conservation in its differential or integrated form, to account for the different components (rainfall, irrigation, run-off, deep drainage and evapotranspiration). Several authors used this approach, among them Rose \& Stern (1967), Reichardt et al. (1979) and Villagra et al. (1995). The methodology is based on the sum of all quantities of water that enter and leave a given soil volume in a given time interval, resulting a net amount of available water for the crop. Each component is evaluated with different techniques (Moura et al., 1994) and, in spite of all difficulties and errors involved in their estimation, the complete field water balance constitutes an important criterion to help crop management. On the other hand, Reichardt et al. (1990) indicate the important fact that imposes difficulties to the water 
balance methodology, which is that of an element soil volume, open at its bottom, a fact that complicates the quantification of its capacity to store water that would be available to plants. Another problem is the spatial variability of soil physical properties. This variability was studied by several authors (Greminger et al., 1985; Villagra et al., 1988) who indicated its importance but did not discuss their implications in the water balance calculations. Villagra et al. (1995) point to the fact that the method demands a considerable amount of equipment at the upper (soil surface) and lower (root zone) limits of the element of volume, which constraints spatial variability studies that require a large number of observations. As a consequence, according to these authors, few papers discuss the difficulties imposed by spatial variability in the study and calculation of water balances.

The water balance components that apparently can be evaluated more easily are rainfall and irrigation. Soil water storage of the soil profile under consideration, is made by integration of soil water content profiles. Neutron probes have been shown to be very convenient for soil water content measurements (Greacen, 1981). Among problems of their use, soil spatial variability of soil water content and probe calibration, stand out as the most important. Turatti \& Reichardt (1991) studied the temporal and spatial variability of soil water storage in an Oxic Haplustox and have shown that the variability is large along a $125 \mathrm{~m}$ transect, however stable in time, wetter points being always wetter for different soil-crop conditions, a point that is discussed by Reichardt et al. (1997) as being related to calibration.

The direct measurement of run-off in the field is laborious since experimentation has to take into account its dependency on soil type and its physical properties, surface cover and length and degree of the slope. Therefore, in many situations, the run-off is left as an unknown in the balance equation and, in this case, all others components have to be known.

Internal drainage and upward soil water fluxes are the components of greatest complexity in the calculation procedures of water balances. For their estimation, a common procedure is the use of the Buckingham-Darcy equation, which involves the soil hydraulic conductivity $\mathrm{K}(\theta)$ function. The soil hydraulic conductivity is, therefore, an indispensable parameter for the use of this theory and, according to van Lier \& Libardi (1999) it is one the most important properties for studies that involve water infiltration, water flow in the soil profile and to plant roots. Despite all this, the information about the variability of the empirical parameters that define the $K(\theta)$ relations is scarce. One of the most commonly used methodologies to estimate $K(\theta)$ is that of the instantaneous profile (Hillel et al., 1972 and Libardi et al., 1980). The advantage of this method is the fact it is based on direct field measurements, which, however, imply in a great investment of equipment, time and labor, specially in soils with dense and compacted layers in which the drainage process is very slow. For this reason few reports on $\mathrm{K}(\theta)$ determinations using instantaneous profile, with a large number of replicates are available. It is also important to mention that Govindaraju et al. (1992) discuss the fact that the methods based on Richards's equation, as it is the case of the instantaneous profile, although theoretically correct involve great problems for their application in order to obtain meaningful input data for water balance calculations. Reichardt et al. (1998) also make a strong discussion on the measurement and difficulties of the use of the $K(\theta)$ relations.

Soil hydraulic conductivity is among the soil physical properties of highest variability, presenting, in most cases, a $\log$ normal distribution. Warrick \& Nielsen (1980) present data with coefficients of variation of the order of $100 \%$ for saturated soil hydraulic conductivity, and of $400 \%$ for unsaturated soil hydraulic conductivity in a drier condition. Libardi \& Saad (1994) state that it is common to find water balance studies based on an unique measurement of hydraulic conductivity being valid only for the experimental plot at which it was measured. This leads to errors in the estimation of the internal drainage and upward soil water fluxes for water balance calculations.

Although having in mind the effect of different soil covers on the water balance components, main objective of this study is to show that although the concept of water balance being simple and straightforward, its quantification for a given crop is extremely difficult and complicated.

\section{MATERIAL AND METHODS}

The experiment was carried out at Piracicaba, SP, Brazil on a Rhodic Kandiudalf, locally called "Terra Roxa Estruturada". According to Koeppen's classification, the climate is of type Cwa, tropical highland, mesothermal with a dry winter, in which the mean temperature of the coldest month is less than $18^{\circ} \mathrm{C}$ and that of the hottest month greater than $22^{\circ} \mathrm{C}$. Mean values for air temperature, rainfall, and relative humidity are $21.2^{\circ} \mathrm{C}$; $1,253 \mathrm{~mm}$ per year; and $74 \%$, respectively. The dry season covers June-August, July being the driest month. During springsummer, October to March, very high intensity rainfall events are common, several of them reaching values of $50 \mathrm{~mm} \mathrm{~h}^{-1}$ or even more.

\section{Experimental design}

The study was carried out in a sugarcane field (variety SP $80-3280$ of medium to late cycle), having a spacing of $1.4 \mathrm{~m}$ between rows, using a completely randomized block design with three treatments and four replicates. Sugarcane is planted in leveled furrows, a practice that minimizes run-off. The field of the experimental plots has a slope of $7.4 \%$, so that every 15 rows $(21 \mathrm{~m})$, are separated by terraces, for the control of high intensity rainfall events. The total experimental area consisted of 15 cane rows, $100 \mathrm{~m}$ long, the central three (numbers 7,8 and 9) having been used for measurements of soil water content and soil water potential (Figure 1). Treatment $T_{1}$ consists of bare interrows; $T_{2}$ of mulched interrows using trash (straw + tips) left on soil surface after harvest; and $\mathrm{T}_{3}$ of burnt interrow trash.

\section{Water balance}

To evaluate the water balance of all treatments, the following mass balance equation was used:

$$
\mathrm{P}+\mathrm{I}-\mathrm{ET}-\mathrm{R} \pm \mathrm{Q}_{\mathrm{L}}=\Delta \mathrm{S}
$$

where all variables $(\mathrm{mm})$ were estimated in time intervals $\Delta \mathrm{t}$ (days), $\mathrm{P}$ being the rainfall; I irrigation; ET evapotranspiration; 


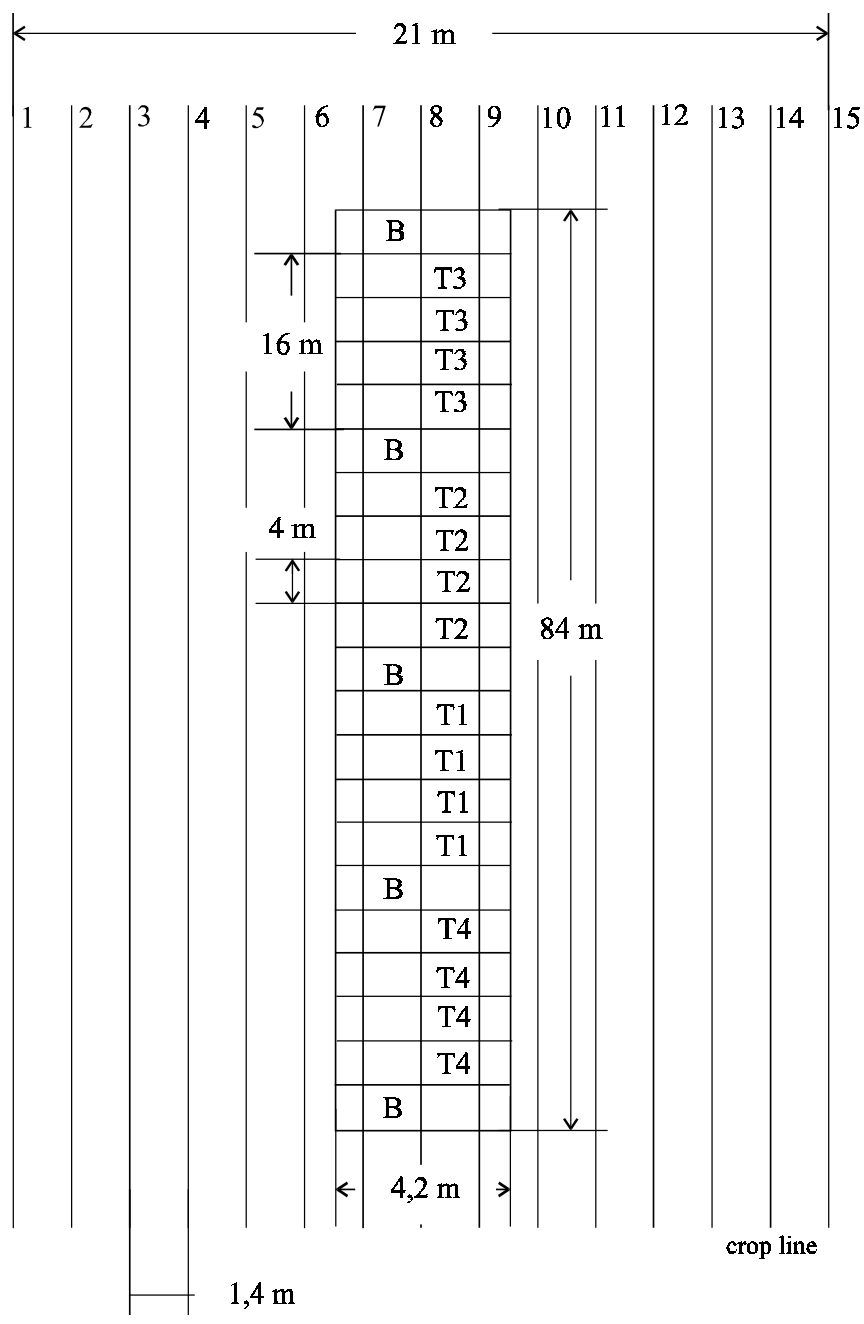

Observation: The three central lines $(7,8,9)$ were used for the water balance study. $\mathrm{T}_{1}$ - bare soil; $\mathrm{T}_{2}$ - mulched soil using trash left on soil surface after harvest; $\mathrm{T}_{3}$ - burnt soil trash; B: border

Figure 1. Experimental design consisting of 15 cane rows, spaced $1.4 \mathrm{~m}, 100 \mathrm{~m}$ long

$R$ run-off; $Q_{L}$ soil water fluxes at the lower limit of the element volume, located at depth $\mathrm{z}=\mathrm{L}$, taken as the limit of the root zone; and $\Delta \mathrm{S}$ the soil water storage change in the 0 - $\mathrm{L}$ layer.

Rainfall was measured at the experimental site, using the mean of two "Ville de Paris" rain gauges, located at both ends of the site (100 m apart). Irrigation was not used, a common practice for the sugarcane crop in this area.

For periods without rainfall, run-off was obviously nil, and evapotranspiration was calculated from the balance Eq. (1). For wet periods, due to difficulties in estimating the run-off within the experimental plots, evapotranspiration was estimated through the Penman-Monteith equation (Pereira et al., 1997), and the run-off calculated from the balance Eq. (1). Data to calculate evapotranspiration were collected at a meteorological station located $1 \mathrm{~km}$ far from the experimental plot. Due to the different soil covers and crop stages, the crop coefficients to be used in the calculations were estimated as per Table 1.

The largest differences of these coefficients in relation to treatments correspond to the months of November and December, when plant canopies did not fully cover soil surface, and the treatments had an effect on evapotranspiration.

Soil water flux densities at the lower limit of the element volume were estimated using the Darcy-Buckingham equation, integrated over the respective water balance time (days) intervals:

$$
\mathrm{Q}=\int_{\mathrm{ti}_{\mathrm{i}}}^{\mathrm{tf}}[-\mathrm{K}(\theta) \operatorname{grad} \mathrm{H}] \mathrm{dt}
$$

where $\mathrm{K}(\theta)$ is the soil hydraulic conductivity $\left(\mathrm{mm} \mathrm{day}^{-1}\right)$, grad $\mathrm{H}$ the soil water hydraulic gradient $\left(\mathrm{m} \mathrm{m}^{-1}\right)$, and $\mathrm{t}$ the time (day). Time intervals $\Delta t=\left(t_{f}-t_{i}\right)$ were of the order of 7 to 15 days.

Hydraulic gradients were calculated from tensiometer readings, four replicates per treatment. The chosen lower limit $\mathrm{z}=\mathrm{L}$ was $1.00 \mathrm{~m}$, since most of the water active root zone is within this layer, and therefore, tensiometers were installed at the depths of 0.9 and $1.1 \mathrm{~m}$, in order to measure the hydraulic gradient by finite difference:

$$
\operatorname{grad} \mathrm{H}=\left(\mathrm{H}_{1.10}-\mathrm{H}_{0.90}\right) / 0.2
$$

where $\mathrm{H}$ is the hydraulic soil water potential, taken as the sum of the matric and the gravitational potentials.

The hydraulic conductivity function $K(\theta)$, for $z=L$, was obtained from measured data collected in an area of $18 \mathrm{~m}^{2}$ at the lower end of the experimental site, using the instantaneous profile method (Hillel et al., 1972 and Libardi et al., 1980), adapting the methodology to a sloping field. Soil leveling was minimized, flooding soil surface in three adjacent platforms of $1.4 \times 4.0 \mathrm{~m}$, and assuring only vertical flow (Timm et al., 2000).

Neutron probe access tubes were installed down to the depth of $1.2 \mathrm{~m}$, one in each replicate, summing up to 12 . The calibration of the depth neutron probe, model CPN 503DR, was made in plots adjacent to the experimental site, correlating probe measurements with volumetric soil sampling data. Soil water content measurements were made at the depths of $0.20,0.40$, $0.60,0.80$ and $1.00 \mathrm{~m}$ on chosen dates $\mathrm{t}_{\mathrm{i}}$. The measurement period ranged over the initial cane development stage, when plants did not cover the soil fully, when treatments would most likely affect the water balance (November through March). Soil water storage $\mathrm{S}(\mathrm{mm})$ were calculated using the trapezoidal method for each date, and their changes $\Delta \mathrm{S}$ used in Eq. (1). Twelve periods of the rainy season were chosen from 27 November 1998 to 29 March 1999 for the calculation of the water balances of each treatment. During the dry season, April to September, rainfall is minimum and the sugarcane enters the maturation period.

\section{RESULTS AND DISCUSSION}

Except for the first studied period, rainfall occurred in all the other 11 periods, since all these belong to the rainy season of Piracicaba. As already mentioned, in the water balance equation rainfall and irrigation are, apparently, the components of easiest estimation since, according to Downey (1972), the errors involved in their measurement can be reduced to $5 \%$ or even $1 \%$ if correct techniques are employed. Reichardt et al. (1995) show that the spatial variability of the rainfall has to be taken 
into account and that it has to be measured as close as possible to the experimental site, which was the case of this experiment.

The high rainfall, in quantity and in intensity, and the soil slope of $7.4 \%$ gave rise to considerable values of run-off despite the fact of leveled furrow planting. The highest rainfall event occurred on 3/11/1999, totalizing $108.2 \mathrm{~mm}$. Other examples are: 26/1/1999, $69.3 \mathrm{~mm}$; and 12/5/1998, $47.0 \mathrm{~mm}$. This confirms the statements of Pereira et al. (1974) that in crops like coffee, which in many aspects is similar to sugarcane, run-off could only be neglected for slopes less than $3 \%$.

Figure 2 presents soil water storage changes for the period under consideration (124 days, November to March), which do not show an evidence of treatment effects. The highest observed soil water storage $(0$ to $1 \mathrm{~m})$ were of the order of $410 \mathrm{~mm}$, whereas the driest, of the order of $310 \mathrm{~mm}$, showing the relatively small water storage capacity of this soil. Although being a clayey soil, this soil fraction is mostly constituted of 1:1 clay minerals and iron oxides, of very low water holding capacity.

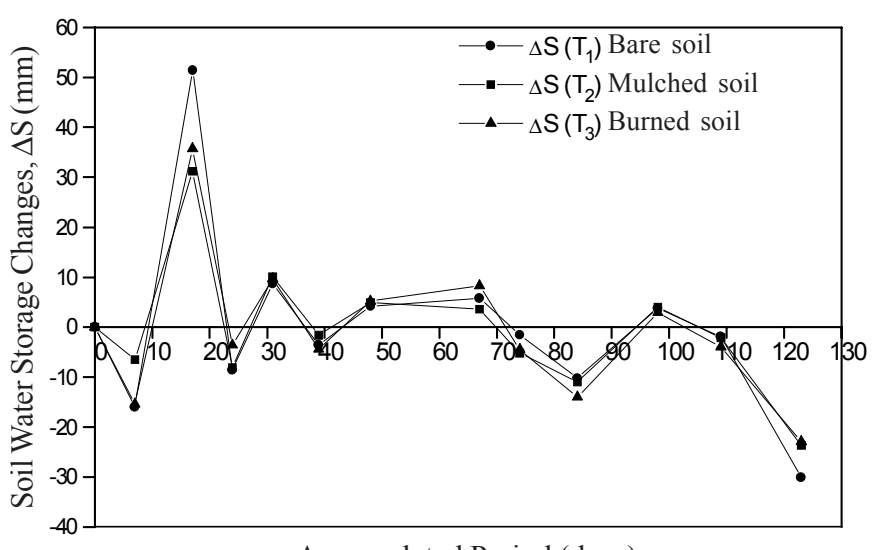

Accumulated Period (days)

Figure 2. Soil water storage changes $(\Delta \mathrm{S})$ for the period under consideration (124 days, November to March)

In order to verify if there are differences of soil water storage among treatments, ANOVA was performed using dates as replicates. No significant difference was found at $p=0.01$. It can therefore be said that the mulching and burning of sugarcane trash does not interfere in soil water storage, at least for the studied crop conditions.

The behavior of the soil water fluxes $Q_{L}$ at the lower limit of the considered soil volume $(\mathrm{z}=1.00 \mathrm{~m})$ is shown in Figure 3. For the first 40 days values of drainage were small since the soil profile was in a recharge process. After this these became very large, assuming values as high as $80 \mathrm{~mm} \mathrm{~d}^{-1}$, due to the high rainfall period and to the low storage capacity of the profile. Although high, these values are 24 times lower than $\mathrm{K}_{\mathrm{o}}$ $\left(1,947 \mathrm{~mm} \mathrm{~d}^{-1}\right)$, the saturated hydraulic conductivity of this soil at the same depth (Timm et al., 2000). Cintra et al. (2000) also measured values of $\mathrm{Q}_{\mathrm{L}}$ this order of magnitude. As mentioned, this internal drainage was estimated through the DarcyBuckingham equation, involving the estimation of soil hydraulic conductivities and gradients. Individual values of each replicate differ so much among themselves, that it becomes prohibitive to take averages and, if taken, their representability of the overall field drainage process becomes very questionable. The use of this approach has been criticized extensively and, more recently by Reichardt et al. (1998). One of the major problems related to this approach is soil variability. According to Warrick \& Nielsen (1980), who classified soil parameters in relation to their spatial variability in low, medium and high, soil hydraulic conductivity has a high variability, presenting a range of coefficients of variation from 170 to $400 \%$. On the other hand, as mentioned in the introduction, Govindaraju et al. (1992) state that $\mathrm{K}(\theta)$ determinations based on Richards equation, lead to complications in their application. The unit gradient approximation used by Libardi et al. (1980), adopted by Timm et al. (2000) and strongly criticized by Reichardt (1993) is another problem to be taken in account.

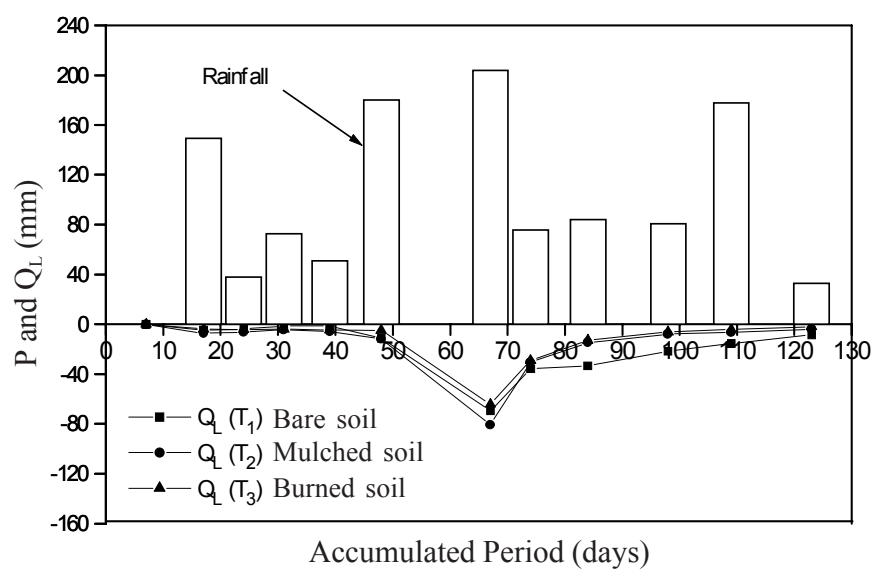

Figure 3. Rainfall $(P)$ and soil water fluxes $\left(Q_{L}\right)$ at the lower limit of the considered soil volume $(\mathrm{z}=1.00 \mathrm{~m})$ for the period under consideration (124 days, November to March)

The most commonly used model for the hydraulic conductivity function is $\mathrm{K}(\theta)=\mathrm{K}_{\mathrm{o}} \exp \gamma\left(\theta-\theta_{\mathrm{o}}\right)$ in which the parameters $K_{0}$ and $\theta_{0}$ can be seen as model fitting parameters (Reichardt et al., 1998). The saturated water content $\theta_{\mathrm{o}}$ should be equal to the total soil porosity, however, several reports show smaller values despite the fact that soil is water pounded until steady infiltration. The explanation for this is the difficulty of fully saturating a soil profile in the field, a fact that leads to errors in the determination of $\theta_{0}$, and as a consequence, to large errors in the estimation of $K$ since the $K(\theta)$ relation is exponential. This is an evidence of the importance of having reliable values of $\theta_{0}$, and of the difficulty of the choice of the best method for its evaluation, which indicates the possibility of making its value more flexible, as already stated by Reichardt et al. (1998) who assumed $\theta_{\mathrm{o}}$ as a fitting parameter. In the present study the best values of $\theta_{0}$ corresponded to: 0.540 for $\mathrm{T}_{1} ; 0.483$ for $\mathrm{T}_{2} ; 0.480$ for $\mathrm{T}_{3}$, all in $\mathrm{m}^{3} \mathrm{~m}^{-3}$.

A similar discussion can be made about the difficulty of estimating $\mathrm{K}_{0}$, also mainly due to its spatial variability and the difficulty of achieving the steady state infiltration condition, i.e., the complete saturation of the profile. For the present case, the mean value of 9 measurements of $\mathrm{K}_{\mathrm{o}}$ was $1,947 \mathrm{~mm} \mathrm{~d}^{-1}$, with a coefficient of variation of $41.3 \%$. The high $\mathrm{CV}$ is also an evidence of the importance of reliable values of $\mathrm{K}_{\mathrm{o}}$ to estimate $\mathrm{Q}_{\mathrm{L}}$. 
The hydraulic gradient calculated according to Eq. (3) also presented a large variability among replicates, due to large differences in tensiometer readings. Coefficients of variation of the four replicates of each treatment, varied from 5.9 to $53.8 \%$. This variability added to that of the $K(\theta)$ values, is of great importance for the calculation of the $\mathrm{Q}_{\mathrm{L}}$ values, using Eq. (2).

With respect to the treatments of this sugarcane management study, it can be seen in Figure 3 that treatments did not affect soil water fluxes at depth L, which was proved using ANOVA.

Figure 4 presents run-off data. Rose (1966) and Mendes et al. (1992) verified that this component is of difficult estimation due to the proportions of its magnitude, to the water volume, slope and soil type. Therefore, in this study, run-off was left as an unknown in the water balance equation, an approach that demands the knowledge of all other components, and that involves all possible errors of the estimation of the other components.

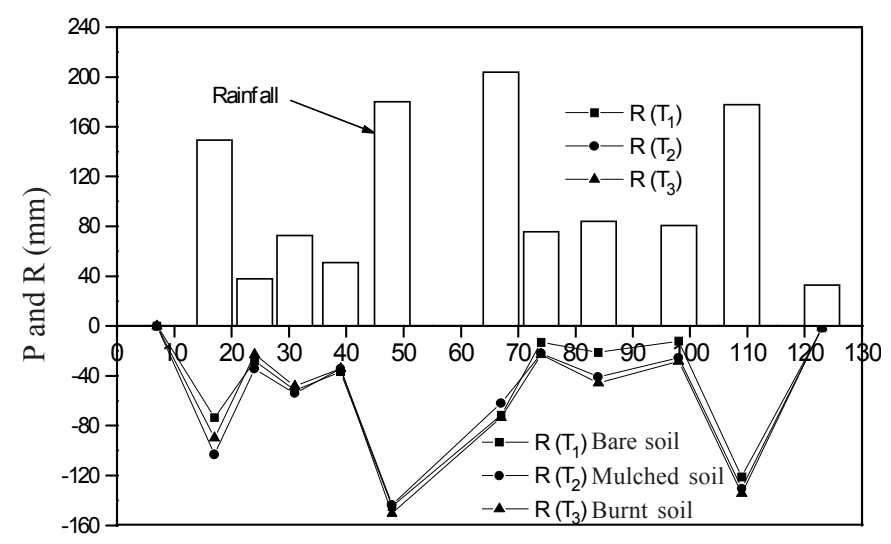

Accumulated Period (days)

Figure 4. Rainfall $(\mathrm{P})$ and run-off $(\mathrm{R})$ for the period under consideration (124 days, November to March)

As it can be seen in Figure 4, very high values were obtained, with no significant differences between treatments (ANOVA). Very high rainfall events are the reasons for these high run-off values. From the rainfall input, part of the water leaves the system by evapotranspiration, another by internal drainage and run-off, the rest remaining in the soil. As discussed, soil water storage has a low limit, and can be affected by soil surface conditions like crusting, compaction, cracking, and mulching. For high rainfall periods, these factors lead to greater run-off values, in this case study. On the other hand, the wetter the soil profiles, the higher the $\theta$ and $\mathrm{K}$ values, implying in greater values of $Q_{L}$. The high run-off values measured in this study are due to the high rainfall values that occurred during the whole study period, due to the slope of $7.4 \%$ of the field and due to the soil compaction level caused by intensive people traffic during measurements.

\section{CONCLUSIONS}

The change of the sugarcane management practice of burning trash after harvest, to the practice of leaving trash as a mulch for the next ratoon crop did not affect any of the following water balance components: run-off, soil water fluxes at the lower soil volume limit and soil water storage. This is due to the characteristics of the sugarcane crop and rainfall pattern. Being a semi-perennial crop after 60 to 90 days it covers completely the soil surface hence, mulching has effects only on evapotranspiration, during the first 90 days. For the high intensity rainfall, the mulch does not alter the water infiltration process and, as a consequence, run-off values are also not altered.

The establishment of the water balance of the sugarcane crop, under the prevailing conditions, is problematic mainly due to the run-off and soil water fluxes at the lower soil water limit, which are strongly affected by the soil spatial variability.

\section{ACKNOWLEDGEMENTS}

This research was supported by FAPESP and CNPq.

\section{LITERATURE CITED}

Cintra, F.L.D.; Libardi, P.L.; Saad, A.M. Water balance in soil for citrus rootstocks in the Brazilian coastal tableland ecosystem. Brazilian Journal of Agricultural and Environmental Engineering, Campina Grande, v.4, p.23-28, 2000.

Downey, L.A. Water-yield relation for nonforage crops. Journal of the Irrigation and Drainage Division, New York, v.98, p.107-115, 1972.

Govindaraju, R.S.; Kavvas, M.L.; Rolston, D.E.; Biggar, J. Error analyses of simplified unsaturated flow models under large uncertainty in hydraulic properties. Water Resources Research, Washington, v.28, p.2913-2924, 1992.

Greacen, E.L. Soil water assessment by the neutron method. Adelaide: CSIRO Publishing 140p, 1981.

Greminger, P.J.; Sud, Y.K.; Nielsen, D.R. Spatial variability of field measured soil-water characteristics. Soil Science Society of America Journal, Madison, v.49, p.1075-1081, 1985.

Hillel, D.; Krentos, V.D.; Stylianau, Y. Procedure and test of an internal drainage method for measuring soil hydraulic characteristics in situ. Soil Science, Baltimore, v.114, p.395-400, 1972.

Libardi, P.L.; Reichardt, K.; Nielsen, D.R.; Biggar, J.W. Simple field methods for estimating the unsaturated hydraulic conductivity. Soil Science Society of America Journal, Madison, v.44, p.3-7, 1980.

Libardi, P.L.; Saad, A.M. Water balance in beans crop, under center pivot. Brazilian Journal of Soil Science, Campinas, v.18, p.529-532, 1994.

Mendes, M.E.G.; Villagra, M.M.; Souza, M.D.; Bacchi, O.O.S.; Reichardt, K. Water relations in a rubber-tree plantation of Piracicaba, SP. Scientia Agricola, Piracicaba, v.49, p.103-109, 1992.

Moura, M.V.T.; Marques Jr., S.; Botrel, T.A.; Frizone, J.A. Estimation of carrot water consumption (Daucus carota L.) v. Nantes superior, in Piracicaba county through the water balance methodology. Scientia Agricola, Piracicaba, v.51, p.284-291, 1994.

Pereira, A.R.; Ferraz, E.S.B.; Reichardt, K.; Libardi, P.L. Estimativa da evapotranspiração e da drenagem profunda em cafezais cultivados em solos podzolizados Lins e Marília. Piracicaba: CENA Publishing 14, 1974.13p. 
Pereira, A.R.; Villa Nova, N.A.; Sediyama, G.C. Evapo(transpi)ração. Piracicaba: Fundação de Estudos Agrários Luiz de Queiroz (FEALQ). 1997. 183p.

Reichardt, K. Unit gradient in internal drainage experiments for the determination of soil hydraulic conductivity. Scientia Agricola, Piracicaba, v.50, p.151-153, 1993.

Reichardt, K.; Angelocci, L.R.; Bacchi, O.O.S.; Pilotto, J.E. Daily rainfall variability at a local scale (1,000 ha), in Piracicaba, SP, Brazil, and its implications on soil water recharge. Scientia Agricola, Piracicaba, v.52, p.43-49, 1995.

Reichardt, K.; Libardi, P.L.; Moraes, S.O.; Bacchi, O.O.S.; Turatti, A.L.; Villagra, M.M. Soil spatial variability and its implications on the establishment of water balances. In: World Congress of Soil Science, 14, Kyoto, 1990. Anais... Kyoto: International Society of Soil Science, 1990, v.1, p.41-46.

Reichardt, K.; Libardi, P.L.; Saunders, L.C.V.; Cadima, Z.A. Dynamics of water in soil cropped with corn. Brazilian Journal of Soil Science, Campinas, v.3, p.1-5, 1979.

Reichardt, K.; Portezan, O.; Bacchi, O.O.S.; Oliveira, J.C.M.; Dourado Neto, D.; Pilotto, J.E.; Calvache M. Neutron probe calibration correction by temporal stability parameters of soil water content probability distribution. Scientia Agricola, Piracicaba, v.54, p.17-21, 1997.

Reichardt, K.; Portezan, O.; Libardi, P.L.; Bacchi, O.O.S.; Moraes, S.O.; Oliveira, J.C.M.; Falleiros, M.C. Critical analysis of the field determination of soil hydraulic conductivity functions using the flux-gradient approach. Soil \& Tillage Research, Amsterdam, v.48, p.81-89, 1998.
Rose, C.W. Agricultural physics. Oxford: Pergamon Press, 1966, 230p.

Rose, C.W.; Stern, W.R. Determination of withdrawal of water from soil by crop roots as a function of depth and time. Australian Journal of Soil Research, Sydney, v.5, p.11-19, 1967.

Timm, L.C.; Oliveira, J.C.M.; Tominaga, T.T.; Cassaro, F.A.M.; Reichardt, K.; Bacchi, O.O.S. Soil hydraulic conductivity measurement on a sloping field. Brazilian Journal of Agricultural and Environmental Engineering, Campina Grande, v.4, p.480-482, 2000.

Turatti, A.L.; Reichardt, K. Soil water storage variability in "Terra Roxa Estruturada". Brazilian Journal of Soil Science, Campinas, v.15, p.253-257, 1991.

van Lier, Q.J.; Libardi, P.L. Parameter variability of the equation relating hydraulic conductivity to soil water content using the instantaneous profile method. Brazilian Journal of Soil Science, Viçosa, v.23, p.1005-1014, 1999.

Villagra, M.M.; Bacchi, O.O.S.; Tuon, R.L.; Reichardt, K. Difficulties of estimating evaporation from the water balance equation. Agricultural and Forest Meteorology, Amsterdam, v. 72, p.317-325, 1995.

Villagra, M.M.; Matsumoto, O.M.; Bacchi, O.O.S.; Moraes, S.O.; Libardi, P.L.; Reichardt, K. Tensiometry and spatial variability in Terra Roxa Estruturada. Brazilian Journal of Soil Science, Campinas, v.12, p.205-210, 1988.

Warrick, A.W.; Nielsen, D.R. Spatial variability of soil physical properties in the field. In: Applications of soil physics. (ed: Hillel, D.). New York: Academic Press, 1980. p.319-344. 